\title{
Move Up or Move Out?
}

The Impact of New Technologies on the Role of the "World Factory" in Supply Chains: Preliminary Remarks by Chinese Analysts

\section{Marisa Siddivò}

\section{(2) OpenEdition \\ 12 Journals}

Electronic version

URL: http://journals.openedition.org/chinaperspectives/7393

DOI: 10.4000/chinaperspectives.7393

ISSN: 1996-4617

\section{Publisher}

Centre d'étude français sur la Chine contemporaine

\section{Printed version}

Date of publication: 1 September 2017

Number of pages: $37-45$

ISSN: 2070-3449

\section{Electronic reference}

Marisa Siddivò, « Move Up or Move Out? », China Perspectives [Online], 2017/3 | 2017, Online since 01 September 2018, connection on 14 November 2019. URL : http://journals.openedition.org/ chinaperspectives/7393; DOI : 10.4000/chinaperspectives.7393 


\title{
Move Up or Move Out?
}

\author{
The Impact of New Technologies on the Role of the "World Factory" in Supply Chains: \\ Preliminary Remarks by Chinese Analysts
}

\author{
MARISA SIDDIVÒ
}

\begin{abstract}
China is equipping itself with a mid-long-term strategy to sustain its manufacturing sector in the face of potential challenges brought about by "disruptive" technologies. According to most analysts, disruptive technologies such as 3D printing, the Internet of things (IoT), big data, and robotics are going to modify the "shop floor" and re-allocate the functions and roles of firms empowered in the global value chains (GVCs). In China, scholars, state officials, and the entrepreneurial community have profoundly analysed the impact that disruptive technologies can exert on their firms' role in the global value chains, reaching the conclusion that the country has to frame a policy to hedge that risk. This paper aims to provide an overview of the debate stirred up by the confrontation of the national manufacturing sector with the introduction of new technologies. The debate, which has involved many institutional and economic actors, has influenced the industrial plans recently drawn up by the Ministry of Industry and Information Technology (MIIT).
\end{abstract}

KEYWORDS: China, disruptive technologies, industrial upgrading, GVCs, entrapment, government plans.

\section{Introduction}

F ollowing Gereffi's intuitions about the benefits of intra-industry relationships (Gereffi 1999, 2005), scholars have stressed the ability of global value chains (GVCs) to create knowledge spill-overs. As asserted by Xiao jiang and William Milberg (2012), "Economic development has become synonymous with 'upgrading' in global value chains, defined as a shifting of production from lower to higher value added parts of global value chains, or the ability of producers to make better products, to make products more efficiently, or to move into more skilled activities." According to most of the literature, the ascendant movement across the value chain requires an appropriate attitude (UNIDO 2002) by supply firms - which, in turn, can be shaped by the institutional framework in which they operate (Pietrobelli and Rabellotti 2011), a balanced governance of the chain by leader firms (Humphrey and Schmitz 2004), and a long-term time frame that lets supply firms learn by doing. When these conditions occur, supply firms can initially experience an ascendant movement in production and then in non-production functions, fostering a comprehensive upgrading process for their country's industrial sector. The success of some East Asian countries, especially Korea, would confirm the postulate of a slow but certain climb by suppliers across the four stages (Humphrey 2004) or five stages (Ozawa 1996, 2014) of industrial upgrading.

The experience of Chinese firms, however, is a controversial issue. Many scholars deem the economic success of this country to be proof of the advantage acquired through partnership with foreign firms within GVCs. Others, especially Chinese scholars, have nurtured many doubts on the ascendant movement by domestic firms that, on the contrary, would have been confined to the assembly stream, where comparative advantage lies in low labour and land costs. Accordingly, "entrapment in comparative advantage" can occur even in those countries where both government and firms are strongly engaged in industrial upgrading.
Hong Kong represents a case in point. As stated in research conducted by the Hong Kong Trade Development Council (2008), in 2003, Hong Kong firms engaged in original equipment manufacturer (OEM), original design manufacturer (ODM), and original brand manufacturer (OBM) represented $82 \%, 62 \%$, and $36 \%$ of the total (number of companies), respectively. In 2007 the respective ratio was $83 \%, 61 \%$, and $40 \%$. Data prove that even in a good investment environment such as Hong Kong's, the transition towards the front- and back-end of the chain is not easy. Another case study is the Chinese province of Guangdong.Yu Hong analysed the Guangdong government's plans to sustain firms' endogenous technology and their efforts to move up the GVC. His findings attest that the province (Yu 2015):

[...] is primarily a low-end assembly and processing base [and that] to cope with the challenge facing Guangdong's industrial development, the provincial government has implemented a number of policies and initiatives with industrial upgrading at the core. However, the government policies are not discernibly effective and local industrial upgrading remains challenging and slow. (p. 32)

A similar scenario to Guangdong has been found in Shanghai. According to a sharp analysis published in April 2015 by the Development Research Centre of the Municipal People's Government, "[Shanghai] in global value chains still takes a subordinate position... [since] the degree of technology of its firms is low and their capacity to withstand international competition is weak" (Development Research Center of Shanghai Municipal Peoples' Government 2015). Yu and Wei (2012) attested that during the first stages of the open door policy, "processing with assembly" was the prevalent form of partnership with foreign invested enterprises (FIEs), while in the 1990s "processing with imported inputs" became more widespread. This change is indicative of China's economic development, with it increasingly adding value to imports rather than simply processing raw materials. From that step, however, most of the enterprises would not have 
been able to further modify their position, remaining confined inside the OEM pattern.

The following evidence is provided by analysts for supporting the theory of "entrapment": the weight of processing exports on total exports, which according to Xing Yuqing $(2012,2013)$ was still "equivalent to $47 \%$ of China's total exports... and to $100 \%$ of trade surplus" by 2010, a more accurate calculation of the trade in added-value (TiVa) of the exported finished goods (Cen 2015), and a different evaluation of the Chinese export sophistication index (Xu 2010; Xu and Lu 2009; Chen and Gong 2014).

Beyond the controversial issues of the debate, a common ground is that a long-term embeddedness among several actors in the supply chain (including institutions) is an essential condition to drive the learning process of suppliers, develop their absorptive capacity, and build an attitude of mutual trust between leader and supplier firms. Indeed, the focus of research pivots on the impact that new technologies, such as 3D printing, (1) internet of things (IOT), (2) robots, and big data, can have on the current global supply chains. Although we are not yet able to evaluate the real effect of these new technologies on trade and production relationships at a global level, we know that polarisation of different stages can occur and that polarisation risks nullifying the efforts of countries that invest in some niches of the supply chain. The rapid prototype, for example, can reduce the role of subcontractors. The possibility of using printers to manufacture parts and components can shorten the intermediate steps of the value chains; the spread of loT may reduce the role of the logistics industry, and so on. In other words, new technologies could, in the near future, re-allocate functions and roles of the countries empowered in GVCs. As suggested by a recent contribution by the WTO (Elms and Low 2013, p. XXII):

Companies' processes, production methods, skills and markets may quickly be rendered redundant by new technological discoveries. Old jobs may disappear as a result of robotics or 3D printing [...]. But disruption means adjustment, and adjustment can be painful and punishing for groups within society.

To date, the impact of new technologies on industry is still limited. Forecasts, however, are very optimistic on the imminent spread of new technologies, since they are backed not only by the need of enterprises to leverage new frontiers of competitiveness but also by political claims. The re-shoring, predicted by Obama, of production processes previously relocated in developing or emerging countries is often quoted as an example. The considerable investment in new technologies by Germany, United States, Japan, and South Korea, which are home to many chain leader firms, would confirm that they are gambling on a new order of business environment at a global level.

This kind of disruptive technology has forced the scientific and policy perspective on supply chains. Issues now are not (only) governance of the chain, preferential policies to attract the leader firms, or the degree of embeddedness among different actors, but who will maintain their supplier role and who will be excluded. Confined until now to the academic and international agencies forum, the debate on how "world factories" can cope with the impact of the so-called "fourth industrial revolution" (3) is spreading in emerging economies. Within the Chinese institutional and entrepreneurship communities, for example, the deficiencies of their firms in facing those disruptive technologies that could weaken the role gained in major global supply chains have become subject to severe reappraisal since 2012. The fear of falling behind has spread over most small-medium enterprises, while the claim for a "natural selection" of those manufacturing sectors that are unable to cope with the new technological revolution has spread in many scientific contributions. At stake, of course, is the role of supplier or assembler played by Chinese firms within some sectors such as transport equipment, machinery, aircraft components, chemical, and automotive parts. To some extent, the supply chains in the consumer electronics industry, where China's weight in terms of supplying components, assembling end products, and recycling e-waste is very great, will also be shortened by the adoption of new technologies. In the domestic debate, however, the risk of losing Foxconn contracts is scarcely mentioned, while concerns about the eventual loss of advantage in technology transfer within high-skilled, knowledge-intensive manufacturing chains have been widely expressed.

Many suggestions have come from the economic actors concerned, most of which, as we will see, have been extensively assimilated by the latest industrial policies. To face up to new challenges, that is, to provide a policy framework for firms' efforts to invest in innovation, governments are designing plans whose approach is more inclusive than in the past. Until recently, Chinese industrial policy had been firmly anchored to the logic of selective intervention - that is, to the selection of a batch of enterprises, sectors, or regions that would benefit from policies for innovation. The need to upgrade the overall manufacturing sector, especially small-medium enterprises engaged in the mid-stream of global supply chains, now seems to prevail over the goal of a streamlined industrial sector based on poles of excellence.

As attested by many analysts, it is still early to assess the real impact of new technologies on the whole manufacturing ecosystem. Consequences in terms of the supply chains and role of the single country's comparative advantages are hard to predict. However, paucity of data is not the only reason to focus on the debate blowing up inside the Chinese economic and political élite. Research on China often suffers from poor knowledge of the climate into which the policymaking process is built. The choice among different opinions stated by economists and/or managers from disparate sources other than official ones is not casual. Although it entails a risk, providing inadequate validity for "objective" research, it aims to offer an insider's view of the actual situation and evidence of an "attentive public" that is even more sensitive to choices of state institutions. The latter, as we will see, reflects, in turn, suggestions from economic actors and the effects of the worsening of the economic situation at both the domestic and international levels, demonstrating that the top-down approach is increasingly invalidated by an even more

1. $3 D$ printing, also known as "additive manufacturing" (AM), is "a process of joining materials to make objects from 3D model data, usually layer upon layer, as opposed to subtractive manufacturing technologies." ASTM International, "Standard Terminology for Additive Manufacturing Technologies," F2792-12a.

2. According to the ITU (The United States specialized agency for Information and Communication), IoT is "A global infrastructure for the information society, enabling advanced services by interconnecting (physical and virtual) things based on existing and evolving interoperable information and communication technologies."

3. The expression "Fourth Industrial Revolution" has rapidly taken over from the expression of "Third Industrial Revolution" earlier coined by Jeremy Rifkin. According to most analysts, it spreads in the literature concerned after the publication of the German Plan "Industry 4.0 " and goes beyond the renewable energies and internet technology predicted by Rifkin as it represents the application of digitalisation to every segment of the production process. 
complex challenge. ${ }^{(4)}$ This paper is structured as follows: the next section presents a review of preliminary research into the impact of disruptive technologies on supply chains. The discourse on risks for local enterprises is then reviewed. The last section is dedicated to plans for the upgrading of manufacturing sectors enacted by the state in recent years.

\section{The impact of new technologies on GVCs}

Since Christensen's (1997) contribution on disruptive technologies, ${ }^{(5)}$ analysts have devoted their attention to the impact that such radical changes can exert on the business model and, in a wider sense, on supply and value chains. Tuck et al. (2007) list the advantages of rapid manufacturing ${ }^{(6)}$ as follows: "dematerialized supply chains; true just-in-time; reduced set up, changeover times and number of assemblers." Along the same lines, Despeisse and Ford (2015) state about additive manufacturing (AM) that:

Looking at the overall manufacturing system configuration, AM enables a shift from traditional mass production methods and economies of scale to small batch production of customised goods at more affordable prices. Moreover, AM can lead to the reconfiguration of the supply chain as fewer components within product assemblies means that fewer actors, stages and interactions may be needed within it, along with a potential reduction in the environmental impacts of logistics.

Baldwin (2013, p. 47) attests that new technologies can undermine the "trade-off between the gains from specialization and the costs of dispersal" until now assured by the fragmentation of the supply chain, and that:

[...] whether these machines end up in high-wage, high-skill nations, or they are distributed to be near every large customer base, the impact would be a very substantial reduction in supply chain trade. To put it sharply, transmission of data would substitute for transportation of goods.

Toth et al. (2015) suggest the opportunity to internalise procedures for product quality control thanks to the use of computed tomography in the inspection of individual implant manufacture using the additive manufacturing technologies. lonescu forecasts that companies will be incentivised "to start producing elements that are now outsourced, leading to an integration strategy, seen as the unification of production, distribution, sales and/or any other economic processes within the same organization" (Ionescu 2015, p. 107). Mohr and Khan (2015, p. 25) summarise the most outstanding research on the impact of $3 \mathrm{D}$ printing on the supply chains with the following words:

Although this disruptive innovation could be devastating for some elements of the supply chain, it can be the start of a revolution for others. Thus, supply chain managers must be aware of the potential impacts that this technology could have on their organization and accordingly, be prepared to react in a flexible and adaptive manner.

Gebler et al. (2014, p. 9) report most of the scientific findings on the impact of the AM on the business model, confirming that:

It is associated with a strong lowering of financial and energy resource inputs into production processes [...]. Production-related labour demands are reduced and are only required for pre-and postprocessing due to the highly automated function principle of the process. Supply chains are vastly affected as 3DP is projected to shorten supply chains through inducing more direct means of production. Furthermore, 3DP is expected to induce shifts towards more localized production and to re-shift production to consumer countries as the share of labour costs in the total production costs decreases.

A recent work by the World Bank likewise warns "companies and countries specialising into standardized production and assembly activities" about the danger of a polarisation of the supply chains as "the distinction between preproduction, production, and postproduction may become less and less relevant" (Taglioni and Winkler 2014, p. 26). The same concern has been expressed by the World Economic Forum, which warns that technology breakthroughs in fields such as artificial intelligence, robotics, the Internet of Things, autonomous vehicles, 3D printing, nanotechnology, biotechnology, materials science, energy storage, and quantum computing run the risk of provoking "greater inequality, particularly in its potential to disrupt labor markets" (Schwab 2015).

Consultancy agencies such as Roland Berger, McKinsey, the IBM Institute for Business Value, TNO, and Deloitte, which handle empirical experiences around the world, converge on the same scenario: from the perspective of developed countries, they stress the opportunity to reduce the outsourcing of some activities in the supply chain as one of the most attractive advantages of 3D printing. They forecast that "the reduced requirement for scale will also have a big impact on the location of production: the optimal manufacturing location by 2022 is regional or local rather than global" (Brody and Pureswaran 2013, p. 10). If this prediction were to come true (Janssen et al. 2014, p. 12):

Sourcing and/or manufacturing in lower-wage countries becomes of less importance. This enables 3-D printing centres to be located in close proximity to home markets in high-wage areas such as Europe and the United States, decreasing the length and complexity of the supply chain and improving the time-to-market.

As advisors, these companies show their concern about the hesitation of firms in grasping the opportunity now that "the cards are being reshuffled" (Roland Berger Strategy Consultant 2014, p. 3), and hold that "by 2025 some manufacturers could be hiring more designers and robotics experts than assemblers" (Manyika et al. 2013, p. 149). As attested by many contributions, however, it is too early to measure the true impact of the adoption of new technologies in manufacturing processes. China, either way, is preparing to face the challenge.

4. Regarding the most recent difficulties for the top-down approach, see Ernst 2015.

5. The decision to focus on additive manufacturing was determined by the simple reason that it has been often considered a symbol of the "fourth industrial revolution" both because it is strictly related to the need to save resources and because of its disruptive impact on the shop floor. The literature is also far more approachable to non-experts such as the author. 3D printing is known to be associated with both the firms' manufacturing process and the individual consumer's involvement in the production of personalised goods. This paper only deals with the business application.

6. "Rapid Manufacturing (RM) is evolving from Rapid Prototyping (RP) technologies that have been successfully used to physically visualise designs and concepts. Rapid Manufacturing is concerned with the direct manufacture of parts and components using additive manufacturing techniques" (Tuck, Hague and Burns 2007). 


\section{China's response to the "Fourth industrial revolution"}

\section{The domestic debate}

In 1985, the well-known Chinese economist Ma Hong ${ }^{(7)}$ wrote (China Development Research Foundation 2014, p. 154):

A new wave of what could be called 'technological revolution' is sweeping the world. More and more people are talking about it in the United States, Japan and the industrially developed countries of Western Europe, but it has attracted growing attention in the Soviet Union and Eastern Europe countries as well [...]. Some call it the third or the fourth industrial revolution [...]. In economically developed countries new technology clusters have appeared in the field of information technology, biotechnology, new materials technology, new energies technology, in developing oceanic resources and others [...]. In this new technological revolution in the world, each country or region is planning its own responses according to its own specific situation and needs. Naturally we have to undertake the same process.

Actually, serious consideration of the "response" the country had to frame arrived about 30 years later. Although a deep reassessment of the standing industrial development pattern started in the early 2000s when the Chinese leadership launched the slogan "from a large to powerful industrial country," the animated exchange on new technologies, especially 3D printing, has blown up in the Chinese media only in the last few years. Most of the articles started from analysis of the United States' re-industrialisation policy and its commitment to funding research into those new technologies that would reduce production costs and develop high value-added manufacturing on the domestic market. Others took their cue from the effects of the international crisis on the domestic market. China Youth Daily admitted, for example, that interest in the impact of new technologies on the future of Chinese manufacturing had been stirred by the news that Foxconn wanted to "suspend recruitment." (8)

The domestic debate followed the same lines as the international one. Indeed, issues related to scarce access to new raw materials, high costs of equipment, difficulties in mass customisation, risk of patent infringement, and so on mark both the international literature and its Chinese counterpart. In China, however, every contribution depicts a sense of urgency that verges on a defensive attitude. Despite Rifkin's encouraging words on China's capacity to catch up with the new industrial revolution, (9) the tone of the domestic debate was (and still is), in fact, very alarmist. Well in advance of the international observers' assessment of Chinese industry's deficiencies, the domestic debate shed light on the poor attitude of firms toward innovation and the difficulties they could face both in gaining a larger share of the market (large and medium enterprises) and in scaling up their position in GVCs (small and medium enterprises). The risk, for the latter, of being "entrapped" in the labour-intensive segment of the global chains was denounced by several academic contributions, ${ }^{(10)}$ within, as we stated above, the more comprehensive and long-standing debate on the shift of the economic model and the "new industrialisation pattern with Chinese characteristics" (Zhongguo tese de xinxing gongyehua moshi 中国特色的新型工 业化模式). In 2007, the famous economist Wu Jinglian (11) said (Gill, Huang, and Kharas 2007, p. 300):
As they are laggards in terms of service operations, Chinese enterprises are usually reduced to the status of selling their physical labour and engaging in economic activities low in the value chain in terms of value added and profit margins, such as simple processing and assembly; they turn over the hefty profits arising from research and development, design, brand marketing, and financial services to others. The selling price of a product that a Chinese enterprise (original equipment manufacturer) manufactures for a foreign enterprise is very low and usually one-fourth or even one-tenth of that of the vendor. The original equipment manufacturer only obtains a meagre processing income.

Eight years later, the "China (Shenzhen) Global Value Chains Innovation Summit" highlighted that although China was respected at the international level for its leadership in global manufacturing, it still faced a "humiliating" (ganga 尴迌) position inside the global value chains.

The disappointment of $\mathrm{Wu}$ jinglian as well as many other analysts grew stronger as interest in the fourth industrial revolution spread at a global level. A set of disruptive technologies that would modify demand by leader firms could frustrate all the efforts by firms to learn by doing, and consequently could halt the industrial upgrading postulated by both the literature on global value chains and the government's plans. Zhang Monan, (12) for example, said:

Companies in the new industrial revolution are not likely to rely greatly on production systems that were common in the past, such as those that used assembly lines, and will not find manufacturing costs to be one of their most crucial expenses. That means companies will no longer compete quite so much by trying to offer the lowest prices on final products of roughly the same quality. Instead, most will compete by trying to sell products with high added values. Such competition is expected to pose a challenge to China's manufacturing industry, which has an advantage in producing goods on a large scale at a low cost. (13)

The report published by the financial portal "Eastmoney" about the International Conference on "New industrial revolution and additive manufac-

7. Ma Hong (1920-2007) joined the Chinese Communist Party in 1937. In 1952 he was appointed secretary-general of the State Planning Commission. In 1978, after holding some positions in the national chemical industry, Ma founded the Industrial Economic Institute and in 1982 became President of the Chinese Academy of Social Sciences. He has been regarded as one of the fathers of the market-oriented reforms.

8. "3D dayin kaiqi xin gongye geming Zhongguo zhizao neng fou biancheng yinlingzhi" (3D printing starts a new industrial revolution. Can Chinese manufacturing become a leader?), Zhongguo Qingnian Bao, 22 February 2013, http://scitech.people.com.cn/n/2013/0222/c1007-20564994.html (accessed on 24 August 2014).

9. Dr. Jeremy Rifkin from The Climate Group: "China is Very Likely to Play a Leading Role in the Third Industrial Revolution," http://www.theclimategroup.org/what-we-do/news-and-blogs/dr-jeremyrifkin-china-is-very-likely-to-play-a-leading-role-in-the-third-industrial-revolution/.

10. Regarding the role of Chinese manufacturing in the GVCs, see, among others: Kratz and Sun 2009; Liu Yue 2009; Liu Zhihua 2010; Wang 2009; Yao 2013; Zhang and Chen 2009.

11. Wu Jinglian is one of the strongest supporters of the market-oriented reforms in China. In 1952 he joined the Communist Party, but like many other colleagues, he was criticised during the Cultural Revolution. Since 1984 he has been a Research Fellow of the Development Research Centre of the State Council. Wu has received the Sun Yefang Award in Economics five times. According to some sources, the expression "socialist market economy" was coined by Wu.

12. Researcher at the State Information Centre, a Chinese government policy-making think tank affiliated with the National Development and Reform Commission.

13. Zhang Monan, "New Industrial Revolution," China Daily, 5 September 2012, http://www.chinadaily.com.cn (accessed on 26 November 2013). 
ture" (14) expressed the same concern. Referring to the "awkward Chinese manufacture," the author cited factors such as increasing dependence on foreign capital, which moreover was shunting back to developed countries or transferring manufacturing processes to South East Asian countries where labour costs were lower than in China. Finally, introducing the issue of 3D printing, the author lamented the risk of Chinese manufacturers losing their comparative advantage, especially when the logic of the "lean value chain" would prevail, and forecasted that "these new things can have a 'lethal force' (shashang li 杀伤力) for developing countries such as China." (15) Luo Jun, CEO of the Beijing-based Asian Manufacturing Association (AMA), shares their concern over the ability of many enterprises to catch up with the most advanced countries. Comparing the European industrial system with its Chinese counterpart, he says:

First, from the technological point of view, the 3D sector in Europe is much more mature than ours; in particular it is stronger in process technology, investment in R\&D, talent, productive behaviour, materials and so on [...]. Secondly, European enterprises that utilize 3D have a scale far larger than ours; on average their revenues from sales are about one billion RMB while in our country there is no enterprise that gets one billion, or rather there are no enterprises that exceed 50 million.

Although Luo Jun also highlights the advantages of Chinese enterprises in introducing new technologies, in particular 3D printing, he concludes:

This sector in Europe can rely on a complete communication network. When the market starts, it will be ready. We have not begun yet. ${ }^{(16)}$

The well-known economist Yang Hai (17) (2012) wrote:

During the earlier two industrial revolutions, China did not seize the occasion. The result was a backwardness that has buffeted us for one hundred years. This cannot happen for the third one [...]. This is a key problem related to the next generation's happiness, and to the life and death of our nation.

To pile it on, the same economist said that "if China is not able to seal the wave of 3D printing, it will follow the same track that led to the 1840 defeat." (18)

The rhetoric of the Opium War defeat appears inconsistent with the progress made by the country since the second half of the 1990s. The universities of Beijing (Tsinghua University), Xi'an (Xi'an Jiaotong University), Shanghai (Shanghai Jiao Tong University), and Wuhan (Huazhong University of Science and Technology) have focused their research on the new technology and especially on 3D printing since then. Many start-ups are emerging in innovative sectors, ${ }^{(19)}$ many foreign companies such as EOS (Germany), Stratasys (US), Aurora (Taiwan), and Materialise (Belgium) are investing in China, and several analysts, both foreign and domestic, are forecasting a greater role for China in this field. China's achievements in innovative industries and in product and process innovation in some segments of the traditional sector have been extensively investigated by analysts who, from both the domestic and foreign perspectives, confirmed the positive outlook provided by the
MIIT. We know, for example, that China is gaining a larger share in the global market for 3D printers, that it has been ranked third (20) in terms of the number of metal powder additive manufacturing machines introduced, that in 2014 it represented the biggest market for industrial robotics, that according to some market research companies, in 2020 China will continue to dominate the Asia Pacific region's IoT market, and that according to MIIT statistical data:

The rate of utilisation of digitalised equipment in the large-medium enterprises of our country's main industries reached $72.3 \%$. Among them, aviation, aerospace, machinery, shipbuilding, and other industries reached $85 \%$. (21)

The risk of a monopolistic role of the American, European, and Japanese firms in the field of new technologies seems to have been averted. (22)

The lost knowledge transfer from universities to the enterprise community and the scarce spill-over effect within the manufacturing sector are, on the contrary, current causes for concern. What alarms economists is, in fact, the bulk of the manufacturing industry, which apart from some outliers they described as dispersed, dependent on foreign imports in OEM pattern, undercapitalised, and in a word, unable to catch up with the wave of the industrial revolution. In the assessment of many analysts, the chance of losing the leading role in manufacturing appears more grounded than the risk of being excluded

14. Sponsored by the Ministry of Industry and Information Technology (MIIT), the Ministry of Science and Technology (MOST), the Chinese Academy of Social Sciences (CASS), and the Chinese Academy of Engineering, the International Conference on "New Industrial Revolution and Additive Manufacture" was held in Beijing on 26 June 2013. Proceedings of the Conference are available at: http://tech.163.com/13/0626/14/92A64A4F00094NCA_all.html.

15. Eastmoney, "Gongxinbu yantaohui liting 3D dayin" (Discussion of the MIIT in supporting 3Dprinting), http://www.gkong.com 2013/6/28, (accessed on 3 December 2014).

16. Luo Jun, "Guo nei 3D daying chanye weiji si fu yu Ozhou bu zai tong yi shuiping" (The domestic $3 \mathrm{D}$ printing industry is obsessed with crisis and it is not at the same level of the European one), financeqq.com, 21 March 2014, http://cn.world3dassociation.com/meiti/2014-03-21/32085.html (accessed on 12 December 2015).

17. Yang Hai is a member of the State Council and vice-president of "YouChange" the China Social Entrepreneur Foundation.

18. Zhongguo Qingnian Bao, 2013, op. cit.

19. Among them, Beijing Tiertime Technology Co. Ltd; HLH Prototypes; DF Robot's; Chengdu Microenviron Environmental Monitoring Equipment Co. Ltd; Flashforge Corporation; Guangdong Shunde Ultralline 3D Technology Co. Ltd; Guangzhou Yousu.

20. Behind the US (38\%) and Japan (10\%). Data refer to 2014, Woholers Associates, Inc.

21. Zhonghua renmin gongheguo gongye he xinxinhua bu (Ministry of Industry and Information Technology), "Xinxihua he gongyehua shendu ronghe, Zhongguo gongye shuaxin 'shenjiban"' (The deep merger between digitalisation and industrialisation is the "updated version" of Chinese industry), Renmin Ribao, 13 November 2014, http://www.miit.gov.cn/n11293472/n11293832/ n11293907/n11368223/16246683.html (accessed on 12 December 2014).

22. Although the commitment of enterprises and institutions to the fourth industrial revolution coincides with a substantial decline in performance in secondary industry, the Report on the National Plan for 2015 attests that "expenditure on research and development activities (R\&D) was worth $1,422.0$ billion yuan in 2015 , up $9.2 \%$ over 2014 , accounting for $2.10 \%$ of GDP. Of this total, 67.1 billion yuan was appropriated for fundamental research programmes. A total number of 3,574 projects under the National Key Technology Research and Development Programme and 2,561 projects under the Hi-tech Research and Development Programme (the 863 Programme) were implemented. By the end of 2015 , there were altogether 132 national engineering research centres and 158 national engineering laboratories. The number of state validated enterprise technical centres reached 1,187. Accumulatively, 206 venture investment enterprises were established under the support of State Venture Capital Investment Plans for Emerging Industries, with a total fund size approaching 55.7 billion yuan, and an investment to 1,233 venture businesses. Some 2,799 thousand patent applications were accepted from home and abroad, and a total of 1,718 thousand patents were authorized. Till the end of year 2015 , the number of patents in force was 5.478 million, of which 872 thousand were invention patents from home. The number of invention patents per 10,000 people was 6.3. A total of 307 thousand technology transfer contracts were signed, representing 983.5 billion yuan in value, up $14.7 \%$ over the previous year." National Bureau of Statistics of China, Statistical Communiqué of the People's Republic of China on the $2015 \mathrm{Na}$ tional, Economic and Social Development, http://www.stats.gov.cn/english/PressRelease/ 201602/t20160229_1324019.html (accessed on August 2016). 
by the market shares of 3D printing or loT and other newest technologies. The gap between the innovative sectors - which can rely on the favourable wind at the international level, foreign direct investment, and supportive state policies - and traditional industry, ${ }^{(23)}$ whose capacity to innovate is still hard to assess, can be further widened by the new wave. The dualistic pattern that has characterised the country's economic growth can, by consequence, become strengthened. Hence, two distinct suggestions emerge from the domestic debate: one is the acceleration of what many analysts recognise as an irreversible trend that is the "creative destruction" of the traditional sectors and their processes (guocheng 过程), products (chanpin 产品), marketing (yingxiao 营销), and management (guanli 管理) methods. Yang Hai (2012), for example, says:

During the new industrial revolution the government has to change its approach. During the industrial revolution, a large batch of traditional enterprises and traditional sectors must be eliminated. There is death before birth. The government can help backward stateowned enterprises and those old industries that provide much of the fiscal revenue, recognising that they represent a barrier to the renovation of enterprises and to social improvement. The pursuance of high increase rates and the mania for the extensive economic pattern are the opposite of the small scale, individualisation, and diversification that characterise the new industrial model.

The other set of suggestions goes in the opposite direction. It advocates a stronger commitment by economic and institutional actors in disseminating the positive effects of the new technological revolution in every segment of the manufacturing sector, since the competitiveness of national industry is already at stake while new technologies are a long way from replacing traditional manufacturing. Jiang Qiping (24) and Lu Bingheng, (25) for example, voice a more sober evaluation both of the impending impact of 3D printing and the importance of timely engagement by state institutions. Accordingly, $3 \mathrm{D}$ printing "is far from substituting traditional manufacturing" due to the peculiarity and high cost of the resources it depends upon and also because:

\section{[...] the development and maturity of this kind of new technologies} requires a long process. Miracles do not occur overnight. Whether or not it impacts on the production and on the life of people, it is the market that will decide. (26)

Many analyses rehash the heady rise of China in global manufacturing output and the consequent worsening of developed countries' position in international trade. But after listing successes, the same analyses express concern about the imminent recovery of supremacy in manufacturing by more developed countries. (27) Hence the debate turns on the eternal issue of the modernisation of the whole manufacturing sector, especially small-medium enterprises now at risk of being squeezed by "lean value chains." Enhanced by new industrial plans (see the following section) and by the "wave of bankruptcies" (daobi chao 倒闭潮) that have hit many firms in traditional sectors, the debate scrutinises the capacity of the latter to absorb the opportunities delivered by the new technological revolution. To our surprise, a passionate defence of the role that traditional industry can still play came from Jack Ma, the CEO of Alibaba, one of the most outstanding firms in an innovative industry. In 2015, Ma said that "the next 30 years belong to the traditional industries," especially to the small-medium enterprises that operate in traditional production. He forecasted that the diffusion of the Inter- net could help them in the new wave (28) of globalisation by modifying their role inside the global value chains. ${ }^{(29)}$ Jack Ma is not an isolated voice. Since 2015, quite a few scientific contributions associate the role that many national enterprises play within the global value chains with the urgency to adopt 3D printing, loT, or cloud computing. The focus on strategic emerging industries, the selection of national championships, and endogenous innovation is likewise gradually being replaced with concern for small-medium enterprises that have to "be able to free themselves from the OEM position, from coping technology or products and other current characteristics," (30) for the traditional industries that still represent $88 \%$ of the industrial output value, and for the scarce ability to exchange information with more developed countries in the wave of a new technological revolution.

\section{The countermeasures}

For many countries, industrial policy represents a resurgent (and maybe a contingent) task to tackle the recession caused by the 2008 worldwide crisis. The Chinese government, however, has never failed to make use of direct interventions either in a long-term perspective (industrial strategy) or in the short term (ad hoc policies) to promote industrial growth and competitiveness. The recent reappraisal of development trends has rather induced the government to adopt an increasingly detailed approach in industry policy. Both selective and horizontal industrial policies reveal a steady tendency to select with accuracy sectors that must be sustained ("key" or "strategic" and "innovative") and those ("traditional") designed to be restructured. Summing up the extensive domestic and international literature on the most recent Chinese industrial policy, it revolves around the enhancement of the "strategic emerging industries," (31) which will be concentrated in selected districts, ${ }^{\left({ }^{32}\right)}$ where thanks to process, product, and organisational in-

23. It might be useful to find a clear classification of Chinese industry before reporting the debate on the upgrading of the manufacturing sector and the related policies. Both in fact refer to "traditional" and "emerging" industries as well, but without a definite indication of the distinct goals. Most of the literature, however, cites as "traditional" the following industries: iron \& steel, nonferrous metal, building materials, electricity, textile, light industry, electronics.

24. CASS.

25. Xi'an Jiaotong University. Lu exposed his point of view at the International Conference on New Industrial Revolution and Additive Manufacturing. See note 14.

26. Jiang Qiping, "3D dayin, weilai qujue yu shichang" (3D printing, the future depends on the market), Zhongguo Gaige Bao, 26 February 2014, http://www.crd.net.cn/2014-02/26/content_ 10513238.htm2014-02-26 (accessed on 30 December 2015).

27. The publication of the 2016 Global Manufacturing Competitiveness Index by Deloitte, which forecast that the United States would be the most competitive manufacturing nation over the next five years, has naturally exacerbated the tone of comparison.

28. The former wave was characterised, according to Jack Ma, by the dominance of large enterprises originated by developed countries.

29. Alibaba Research Center, "Hulianwang + chuantong qiye: cong yi tiao jiazhilian shuoqi" (Internet Plus and traditional enterprises. From the value chain perspective), http://www.199it.com/archives/373826.html, 2015.08.07 (accessed on 13 January 2016).

30. Xueba (2013), "Zhongguo yong 3D dayin zao Jian 20" (China makes Jet-20 with 3D printing), http://www.360doc.com/content/13/0605/16/10636269_290700374.shtml (accessed on 15 October 2015).

31. The seven strategic emerging industries selected in 2011 are: 1 . New energy auto industry; 2 . Energy-saving and environmental protection industry; 3 . New-generation information technology industry; 4. Biology industry and bio-pharmaceutical industry; 5 . High-end equipment manufacturing industry (aviation equipment, satellite and its application, rail transportation equipment, marine engineering equipment, intelligent equipment-manufacturing industry); 6 . New energy industry (nuclear, wind, solar, and biomass industry); 7. New material industry. The recent "Made in China 2025" has added the following to the list: automated machine tools and robotics; agricultural equipment.

32. "Model districts" and/or the "innovation-based industrial cluster pilots" selected by the MOST in 2011. Of the 74 applicants, the Ministry initially selected 41, and after the promulgation of the "Management Method of Identification of Innovation-based Industrial Cluster Pilots" picked from among them 10 industrial clusters for the first batch. To every cluster a specific project was assigned. 
novation, some designated projects ${ }^{(33)}$ will be carried out. The final goal is a "new pattern of industrialisation with Chinese characteristics."

More recently, however, a different approach has been adopted (Kennedy 2015). The "Internet Plus Action Plan," (34) the "Plan for the Development and Promotion of the National Additive Manufacturing Industry," (35) and the "Made in China 2025 Draft Plan," (36) taking into account suggestions from the domestic debate, international experience, ${ }^{(37)}$ and appraised achievements from earlier policies, represent a more "inclusive" approach that official statements aim at the traditional sector, especially smallmedium enterprises involved in global value chains. The detailed instructions for innovation in the above-cited plans address traditional and innovative sectors and large and small-medium enterprises. The goal is to develop "mass entrepreneurship" (da zhong chuangye 大众创业) and "mass innovation" (wan zhong chuangxin 万众创新) for reducing the gap with developed countries "regarding core technologies, product added value, product quality, efficiency, energy use, environmental protection, and other aspects." (38) The focus on the upgrading of traditional sectors was already evident in the 2011 Plan for "lianhua" (merging of digitalisation and industrialisation). It stated the need to "focus on automotive, aircraft, shipbuilding, machinery, home appliances, electricity [...] to push on the merging between digitalisation and the technical experience of the traditional sectors." (39) Three years later, however, the MIIT admitted that the "lianhua" plan was still facing "many contradictions and problems": (40) according to Miao Wei, the bulk of the manufacturing industry was not yet aware of the urgency of the duties imposed by the plan. From the umpteenth ruthless inventory of the manufacturing industry's weakness, therefore, the MIIT designed long-term strategies to improve ICT infrastructure, education, patent application, and digitalisation of the manufacturing process. If, however, the "Instruction to promote loT" (41) aimed to foster a batch of backbone enterprises, and a batch of small-medium enterprises that are "focused, smart, specialised, and innovative," the "Plan for the Development and Promotion of the National Additive Manufacturing Industry," the Internet Plus Plan, and the Made in China 2025 Plan expand the range of sectors and enterprises that must be involved. The 3D plan, for example, states that "the powerful industrialised countries, where additive manufacturing is becoming the new growth factor for industry, have adopted strategic measures to develop it [...] for us it is urgent to acquire this new technology for upgrading traditional industry." The traditional sector ("machinery, aviation, shipbuilding, automotive, light industry, textile, food, electronics") is required by the "Made in China" Plan "to accelerate intelligent automation in upgrading their capacity in precision and agile manufacturing [...] to occupy medium and high-end markets, resolve the problem of overcapacity, promote the development of large and small-medium enterprises, and improve the industrial layout." All sectors are required by the plan to carry out four missions: expand innovation capacity, improve quality and efficiency, apply digitalisation, and adopt a green development pattern. The concepts of "harmonious development" and "comprehensive industry upgrading" recur frequently, marking a shift as opposed to the fierce competition between the traditional and innovative sectors earlier stirred up by official and academic literature.

\section{Conclusion}

Awareness of the challenge that new technologies are issuing to the "world's factories" has spread in Chinese economic, institutional, and social life. Since 2012, scholars and the entrepreneurial community have debated the impact that new technologies can exert on the relentless but slow process of restructuring the manufacturing industry started by Wen Jiabao in the early years of the new century. Although the confrontation is very recent, we can distinguish three phases. In the first, concern over investment by developed countries in new technologies and the consequent propensity of many GVC leader firms to re-shore prevails in the analysis. Complaints regarding the "humiliating" position of Chinese firms within the global value chains and the disillusion about their moving up (that can be converted to a "moving out") distinguish most of the contributions to the debate. In the second phase, analysts focused on the role that their country's most innovative firms can play within global value chains. The rapid and successful growth of many start-ups in 3D printing, loT, and robotics, and strong support by state institutions likewise indicate an equally rapid and successful change in the role of national industry at the global level. The "Chinese dream" of a powerful industrial country that sheds the image of the "world factory" competing with the most developed countries in the race for technology inspires most of their contributions. In the third phase, both government and scholars recognise that the difficulties of many firms in the traditional sectors are structural rather than cyclical. They also recognise that "innovative" sectors cannot redress the impact of potential resizing of the traditional industry, since they represent little more than $10 \%$ of the industrial output value. Analysts, indeed, turn their attention to compre-

33. The "Twelfth Five-Year Plan for Strategic Emerging Industries" (2012), for example, lists the following projects: "key energy-saving technology and equipment industrialisation project; pilot project for equipment relating to key environmental protection technology and product industrialisation; important resource recycling project; broadband China project; high-performance integrated circuits project; new-type flat panel display project; Internet of things (IoT) and cloud computing technology project; "Beneficial Information for the People" project; protein-based biomedical products and vaccine project; high-performance medical treatment equipment project; bio-breeding project; bio-based material project; aviation equipment project; spatial infrastructure construction project; advanced rail transport equipment and its key assemblies project; marine engineering equipment project; intelligent equipment-manufacturing project; new energy integrated application project; key material upgradation project; new energy auto project.

34. Zhonghua renmin gongheguo guowuyuan (State Council), Guowuyuan guanyu jiji tuijin "hulianwang+"xingdong de zhidao yijian (Guiding Opinions of State Council on "Internet Plus" Action Plan), No. 40, 2015, http://www.gov.cn/zhengce/content/2015-07/04/content_10002.htm (accessed on 21 January 2016).

35. Zhonghua renmin gongheguo gongye he xinxinhua bu (Ministry of Industry and Information Technology), "Guojia zengcai zhizao chanye fazhan tuijin jihua (2015-2016 nian) de tongzhi gongxibu lianzhuang (201) 53 hao" (Notice No. 53 of the Ministry of Industry and Information Technology, the National Development and Reform Commission, and the Ministry of Finance on Issuing the Plan for the Development and Promotion of the National Additive Manufacturing Industry [20152016]), http://www.cac.gov.cn/2015-03/02/c_1114491348.htm (accessed on 24 October 2015).

36. Zhonghua renmin gongheguo guowuyuan (State Council), "Guowuyuan guanyu yifa 'Zhongguo zhizao 2025' de tongzhi guofa" ("Made in China 2025"), No. 28, 2015, http://www.360doc.com/ content/15/0519/17/2457585_471757101.shtml (accessed on 5 October 2015).

37. German industrial plan known as "Industry 4.0."

38. "Miao Wei: Zuo hao xinxihua yu gongyehua shengdu ronghe zhe bian da wenzhang" (The great essay by Miao Wei on the deep merger between digitalisation and industrialisation), Renmin Ribao, 13 November 2014, http://finance.people.com.cn/n/2014/1114/c1004-26022936.html (accessed on 26 November 2014).

39. Zhonghua renmin gongheguo gongye he xinxinhua bu, kejibu, caizhengbu, shangwubu, (Ministries of Industry and Information Technology, Science and Technology, Finance and Commerce ), Guoyou zichan jiandu guanli weiyuanhui (State Owned Assets Supervision and Administration Commission), "Jiakuai tuijin xinxihua yu gongyehua shendu ronghe de guogan yijian" (Opinion on the acceleration of merging between informatisation and industrialisation), No. 160, 2011, http://www.miit.gov.cn/n11293472/n11293832/n11293907/n11368223/13718738.html (accessed on 24 September 2012).

40. "Miao Wei: Zuo hao xinxihua yu gongyehua shengdu ronghe zhe bian da wenzhang" (The great essay by Miao Wei on the deep merger between digitalisation and industrialisation), Renmin Ribao, art. cit.

41. Zhongua renmin gongheguo guowuyuan (State Council), "Guowuyuan guanyu tuijin wulianwang youxu jiankang fazhan de zhidao yijian, Guofa" (Guiding Opinion on the Orderly and Healthy Development of the IOT), No. 7, 2013, http://www.gov.cn/zwgk/2013-02/17/content_ 2333141.htm (accessed on 28 October 2015) 
hensive upgrading of manufacturing activity. The Government's industrial plans reflect suggestions from the domestic debate. Behind the prevailing outcome of each of the three phases, we can single out different interests. The recovery of a salient role for traditional industry in the new economic profile of the country, for example, has been propelled by warnings of massive layoffs by the managers of enterprises that have been placed under the severe assessment of the government. Denunciation of the entrapment of many small-medium enterprises in global value chains has not been shared by many local governments, which on the contrary continue to seize subcontracting opportunities for local enterprises. However, such differentiations are a rough guess. Both discussion and policies reveal a gruelling exercise in compromise by institutional and economic agents that are coming to grips with an even more complex landscape. A paucity of data on the actual effects of the shift in government plans towards a more inclusive approach would confirm their difficulties. A recent report by the State Council on the achievements of "Made in China 2025" (42) confines itself to naming all measures adopted and soon to come into operation at both the central and provincial levels. Moreover, analysing local governments' most recent industrial policies, ${ }^{(43)}$ we get the impression that the hypothesis to build, along the "new silk roads" (Belt and Road Initiative), their own value chains where Chinese enterprises can control backward and forward linkages is more substantial than upgrading their role inside the already established chains. However, to gain validity, this perception requires a different approach and more in-depth research.

\section{References}

BALDWIN, Richard. 2013. "Global Supply Chains: Why They Emerged, Why They Matter, and Where They Are Going." in Deborah K. Elms and Patrick Low (eds), Global Value Chains in A Changing World, WTO and Fung Global Institute.

BRODY, Paul, and Veena PURESWARAN. 2013. The New Software-Defined Supply Chain. Preparing for the Disruptive Transformation of Electronics Design and Manufacturing. New York: IBM Institute for Business Value Executive Report, IBM. http://public.dhe.ibm.com/common/ssi/ecm/gb/en/gbe03571usen/GBE03571US EN.PDF (accessed on 24 August 2015).

CEN Yujun. 2015. "Zhongguo zai quanqiu shengchan wangluo zhong de fengong yu maoyi diwei. Jiyu TiVA shju yu GVC zhishu de yanjiu" (The role of China in the global production net. Based on research on TiVa data and GVC index). Guoji Maoyi Wenti 1.

CHEN Lili, and GONG Jing. 2014. "Zhongguo chukou chanpin fuzadu tisheng le ma?" (Has the sophistication degree of the Chinese export improved?). Shijie Jingji Wenhui 2: 30-44.

China Development Research Foundation (ed.). 2014. Collected Works of Ma Hong. New York: Routledge.

CHRISTENSEN, Clayton M. 1997. The Innovator's Dilemma. When New Technologies Cause Great Firms to Fail. Boston (Mass.): Harvard Business School Press.

DESPEISSE, Melanie, and Simon FORD. 2015. "The Role of Additive Manufacturing in Improving Resource Efficiency and Sustainability." Centre for Technology Management Working Paper Series 3. http://www.ifm.eng.cam.ac.uk/uploads/Research/CTM/working_paper/2015-03-Despeisse-Ford.pdf (accessed on 24 October 2015).

ELMS, Deborah K., and Patrick LOW (eds.). 2013. Global Value Chains in a Changing World.

ERNST, Dieter. 2015. From catching up to forging ahead: China's policies for semiconductors. Honolulu: East-West Center.
In conclusion, for more than a decade, Chinese decision-makers have outlined a batch of policies aimed at selecting those "advanced" districts or sectors or industrial parks that should be the backbone of the new industrialisation pattern with Chinese characteristics. This aim, though still present, has been relegated to a minor role. Of greater importance is the risk of many firms being marginalised on the market and/or within global value chains in which benefits for leader firms will be enhanced in the light of new technologies. This risk is too great to be ignored.

\section{Marisa Siddivò is Assistant Professor at the Department of Asian,} African, and Mediterranean Studies at the Università degli Studi di Napoli "L'Orientale."

Università degli Studi di Napoli "L'Orientale," Piazza San Domenico Maggiore, 12, 80134 Naples, Italy (msiddivo@unior.it).

\section{Manuscript received on 10 April 2016. Accepted on 2 November 2016.}

42. Eastmoney, "'Zhongguo zhizao 2015' zhi yi nian. Guowuyuan xindong chengjidan" (One year after "Made in China 2025": State Council report on achievements), 9 May 2016, http://www.cechina.cn/m/article.aspx?ID=54739 (accessed on 18 September 2016)

43. See, for example, the Guangdong Province Plan for 2016-2018: "Guangdong Sheng Renmin Zhengfu bangongding guanyu yinfa Guangdong Sheng gongye qiye chuangxin qudong fazhan gongzuo fangan" (Plan to drive innovation for industrial enterprises in Guangdong Province, 20162018), http://rs..huizhou.gov.cn/publicfiles/business/htmlfiles/9418/2.2/201606/565279.html (accessed on September 2016).

GEBLER, Malte, Anton J.M. SCHOOT UITERKAMP, and Cindy VISSER. 2014. "A Global Sustainability Perspective on 3D Printing Technologies." Energy Policy 74: 158-167. http://dx.doi.org/10.1016/j.enpol.2014.08.033i (accessed on 20 December 2015).

GEREFFI, Gary. 1999. "International Trade and Industrial Upgrading in the Apparel Commodity Chain." Journal of International Economics 48(1): 37-70.

GEREFFI, Gary. 2005. "The New Offshoring of Jobs and Global Development." International Labour Organization. http://www.cggc.duke.edu/pdfs/20061030_Gereffi_ILO_The_new_offshoring_of_jobs_\&_global_development.pdf (accessed on 27 October 2007).

GILL, Indermit S., Yukon HUANG, and Homi J. KHARAS (eds.). 2007. East Asian Visions: Perspectives on Economic Development. Washington DC and Singapore: World Bank Institute of Policy Studies.

Hong Kong Trade Development Council. 2008. "Study on OEM, ODM and OBM: Extending the Supply Chain with Added Value." HKTDC Economists' Pick. http://economists-pick-research.hktdc.com/business-news/article/EconomicForum/Study-on-OEM-ODM-and-OBM-Extending-the-Supply-Chain-withAdded-Value/ef/en/1/1X000000/1X0040U6.htm\#sthash.Z4lEygs7.dpuf (accessed on 15 October 2013).

HUMPHREY, John, and SCHMITZ, Hubert. 2004. "Chain Governance and Upgrading: Taking Stock." in Hubert Schmitz (ed.), Local Enterprises in the Global Economy. Cheltenham: Edward Elgar. 349-382.

HUMPHREY, John. 2004. "Upgrading in Global Value Chains." International Labour Organization Working Paper 28. http://www.oit.org/wcmsp5/groups/public/—dgreports/_-integration/documents/publication/wcms_079105.pdf (accessed on 15 October 2013).

IONESCU, Alexandra I. Florea. 2015. "The Disruptive Force of 3D Printing on Supply Chains." Business Excellence and Management 5(2): 102-109. 
JANSSEN, Robbert et al. 2014. TNO: The Impact of 3-D Printing on Supply Chain Management.TNO-Innovation for Life. http://3din.nl/wp-content/uploads/2014/ 02/TNO-Whitepaper-3-D-Printing-and-Supply-Chain-Management-April-2014web.pdf (accessed on 25 September 2015).

JIANG, Xiao, and William MILBERG. 2012. "Vertical Specialization and Industrial Upgrading: A Preliminary Note." Capture the Gains Working Paper 10 http://www.capturingthegains.org/pdf/ctg-wp-2012-10.pdf (accessed on December 2015).

KENNEDY, Scott. 2015. "Made in China 2025." CSIS Critical Question. http://csis.org/publication/made-china-2025 (accessed on 3 February 2016).

KRATZ, Agatha, and Lin SUN. 2009. "Quel Avenir pour le Made in China?" (What future for the Made in China?). China Analysis 46: 33-37.

LIU Zhihua. 2010. "Analysis to the Development of the Chinese OEM Enterprise." Proceedings of 2010 International Conference on the Growth of Firms and Management Innovation. http://www.seiofbluemountain.com/upload/product/ 201010/2010qychzh01a13.pdf (accessed on 7 December 2015).

LIUYue. 2009. "Quanqiu jiazhi lian fengong dui Zhongguo zhizaoye de qishi" (What the global value chains reveal about the Chinese manufacturing industry). Zhongguo Shichang 18. https://wenku.baidu.com/view/bd4344cabb4cf7ec4afed07a .html (accessed on 7 December 2015).

MANYIKA, James et al. 2013. Disruptive Technologies: Advances that will Transform Life, Business, and the Global Economy. McKinsey Global Institute. http://www.mckinsey.com/business-functions/business-technology/ourinsights/disruptive-technologies (accessed on 12 December 2015).

MOHR, Sebastian, and Omar KHAN. 2015. "3D Printing and its Disruptive Impacts on Supply Chains of the Future." Technology Innovation Management Review 5(11): 20-25. http://timreview.ca/article/942 (accessed on 12 December 2015).

OZAWA, Terutomo. 1996. "The Macro-IDP, Meso-Idps and the Technology Development Path (TDP)." in John Dunning and Rajneesh Narula (eds), Foreign Direct Investment and Governments. London: Routledge. 142-173.

OZAWA, Terutomo. 2014. "Explaining the Rise of East Asian Multinationals: StateIndustry Links, a Stages Model of Structural Change, and Japan as a Precedent Setter." Center on Japanese Economy and Business Working Paper Series 337.

PIETROBELLI, Carlo, and Roberta RABELLOTTI. 2011. "Global Value Chains Meet Innovation Systems: Are There Learning Opportunities for Developing Countries?" World Development 39(7): 1261-1269.

Roland Berger Strategy Consultant. 2014. Industry 4.0.The New Industrial Revolution. How Europe will succeed. https://www.rolandberger.com/en/Publications/ pub_industry_4_0_the_new_industrial_revolution.html (accessed on 19 November 2014).

SCHWAB, Klaus. 2015. "The Fourth Industrial Revolution: What It Means and How to Respond." World Economic Forum. 15 December 2015. https://agenda.weforum.org/2015/12/the-fourth-industrial-revolution-what-it-means-and-how-torespond/ (accessed on 31 January 2016).
Shanghai Lixin University of Commerce Research Group. 2015. "Tisheng Shanghai zai quanqiu jiazhilian zhong de diwei yanjiu" (How to upgrade the role of Shanghai in the GVCs). Kexue Fazhan 2015(7): 77-90.

TAGLIONI, Daria, and Deborah WINKLER. 2014. Making Global Value Chains Work for Development, Building Global Value Chains 2014. Annual Meetings side event, The World Bank Group. 1-127.

TÓTH, Theodor, Radovan HUDÁK, and Jozef ŽIV ÁK. 2015. "Dimensional Verification and Quality Control of Implants Produced by Additive Manufacturing." Quality Innovation Prosperity / Kvalita Inovácia Prosperita 19(1).

TUCK, Christopher, Richard HAGUE, and Nail D. BURNS. 2007. "Rapid Manufacturing Impact on Supply Chain Methodologies and Practice." International Journal of Services and Operations Management 3(1): 1-22.

UNIDO. 2002. Industrial Development Report 2002/2003: Competing Through Innovation and Learning. https://www.unido.org/fileadmin/user_media/Publications/Pub_free/Industrial_development_report_2002_2003.pdf

WANG Wei. 2009. "Quanqiu shengchan wangluo xia wo guo jiagong maoyi shengji yanjiu" (Research on upgrading of our country processing trade within the global production network). Tianjin Caijing Daxue. http://max.book118.com/ $\mathrm{html} / 2014 / 1215 / 10668673 . s h t m$ (accessed on 15 December 2014).

WTO and Fung Global Institute. Global value chains in a changing world. https://www.wto.org/english/res_e/booksp_e/aid4tradeglobalvalue13_e.pdf (accessed on 6 September 2015).

XING, Yuqing. 2012. "The People's Republic of China's High-Tech Exports: Myth and Reality." ADBI Working Paper 357. Tokyo: Asian Development Bank Institute. https://www.adb.org/sites/default/files/publication/156212/adbi-wp357.pdf (accessed on 6 September 2015).

XING, Yuqing. 2013. Joining Global Production Networks: China's Processing Trade and High-Tech Exports 2013. Tokyo: Asian Development Bank Institute. http://www.carecprogram.org/uploads/events/2013/TOKYO-Global-SupplyChains/009_103_209_Session-20ll-Dr-Yuqing-Xing.pdf.

XU, Bin, and Jiangyong LU. 2009. "Foreign Direct Investment, Processing Trade and the Sophistication of China's Exports." China Economic Review 20(3): 425-439.

XU, Bin. 2010. "The Sophistication of Exports: Is China Special?", China Economic Review 21(3): 482-493.

YANG Hai. 2012. "Di san zi gongye geming, Zhongguo jiang luowu?" (The Third Industrial Revolution, China will be out?). Qiyejia 8.

YAO Jian. 2013. "Wo guo zhong xiao qiye jinhou jiang yi liang zhong moshi canyu quanqiu jiazhilin yu quanqiu fengong" (Hereafter, our country SMEs' different models to take part to the GVCs). Duiwai Jingmao 8: 9-11.

YU, Hong. 2015. Chinese Regions in Change, Industrial Upgrading and Regional Development Strategies. London and New York: Routledge.

YU, Miaojie, and Tian WEl. 2012. "China's Processing Trade." East Asia Forum. 27 October 2012, http://www.eastasiaforum.org/2012/10/27/chinas-processingtrade/ (accessed on 26 November 2013).

ZHANG Yangui, and CHEN Xiaoyan. 2009. "Quanqiu jiazhilian yu Zhongguo Zhizao" (GVCs and Chinese manufacture), Shijie Jingji Yanjiu 10: 8-13. 